\title{
Tradisi Adat Methik Pari Di Desa Kalistail Kecamatan Genteng Kabupaten Banyuwangi (Studi Pendekatan Historis)
}

\author{
Abdul Shomad, Topan Priananda Adinata \\ Program Studi Pendidikan Sejarah, FKIP, Universitas PGRI Banyuwangi
}

\begin{abstract}
Abstrak
Adat methik pari merupakan adat yang ada di Desa Kalistail Kecamatan Genteng Kabupaten Banyuwangi. Adat ini telah ada sejak zaman Nenek moyang orang Jawa, selamatan ini dilaksanakan sebagai wujud syukur petani kepada Tuhan atas keselamatan dalam penggarapan lahan pertanian, dan hasil panen yang melimpah serta dihindarkan dari ganggguan hama. Penelitian bertujuan untuk mengidentifikasi makna, proses pelaksanaan serta peran masyarakat dalam pelestarian tradisi adat methik pari di Desa Kalistail Kecamatan Genteng Kabupaten Banyuwangi. Meode penelitian menggunakan penelitian kualitatif berupa studi kasus. Pengumpulan data dengan observasi, interview, dan dokumentasi. Teknik validasi data dan analisa data yang digunakan adalah analisis interaktif. Hasil penelitian menunjukkan adat selamatan methik pari telah ada sejak zaman nenek moyang masyarakat Jawa di Desa Kalistail. Adat selamatan tersebut memiliki makna bahwa terjalinnya kerukunan dalam bermasyarakat dan sebagai penghubung manusia antara leluhur dan Tuhannya, serta akan diberi keselamatan dalam penggarapan lahan pertaniannya. Oleh karena pengaruh globalisasi, maka adat selamatan tersebut mulai memudar dan menghilang. Peran penjaga adat masih nampak, walaupun regenerasi kurang memahami diperlukan adanya pemahaman tentang pentingnya tradisi tersebut. Mengingat tradisi tersebut merupakan warisan budaya milik Daerah dan dapat dijadikan sebagai aset pengembangan wisata budaya di Kabupaten Banyuwangi, khususnya di Desa Kalistail Kecamatan Genteng, sehingga tidak terlindas oleh arus globalisasi.
\end{abstract}

\section{Kata Kunci: Tradisi, Selametan, Methik Pari}

\section{Pendahuluan}

Melville J. Herskovits dan Bronislaw Malinowski (2002) mengemukakan bahwa segala sesuatu yang terdapat dalam masyarakat ditentukan oleh kebudayaan yang dimiliki oleh masyarakat itu sendiri. Istilah untuk pendapat itu adalah CulturalDeterminism. Hardt (2004) memandang kebudayaan sebagai sesuatu yang turun temurun dari satu generasi ke generasi yang lain, yang kemudian disebut sebagai superorganic. Kebudayaan merupakan keseluruhan yang kompleks, yang di dalamnya terkandung pengetahuan, kepercayaan, kesenian, moral, hukum, adat istiadat, dan kemampuan-kemampuan lain yang di dapat seseorang sebagai anggota masyarakat. Menurut Shomad budaya adalah keseluruhan sistem gagasan tindakan dan hasil karya manusia dalam rangka kehidupan masyarakat yang dijadikan milik diri manusia dengan cara belajar. Sedangkan adat adalah gagasan kebudayaan yang terdiri dari nilai-nilai kebudayaan, norma, kebiasaan, kelembagaan, dan hukum adat yang lazim dilakukan di suatu daerah. Mengetahui dan melestarikan adat dan budaya adalah hal penting. Supaya sebagai manusia Indonesia dapat memiliki identitas diri dan tidak 
mudah terombang ambing dalam mengahadapi tantangan globalisasi, serta literalisasi yang sarat dengan nilai-nilai baru dan asing. Memang tidak mudah untuk dapat menjaga atau mempertahankan adat dan budaya warisan leluhur. Oleh karena adanya anggapan bahwa adat merupakan leluhur kuno. Faktor ini adalah keterbatasan orang-orang memahami dan mengetahui tentang apa dan bagaimana adat itu. Dengan begitu tidak heran jika ada adat suatu daerah yang mulai punah dan cenderung dilupakan.

Adat selamatan pari dilakukan saat menjelang panen pari, di mana pari sudah tua menguning. Harapannya adat upacara selamatan pari mampu menyuburkan tanaman pari. Selain itu, dapat pula membuat hasil panen pari melimpah, sehingga dapat di simpan dalam lumbung pari. Sebab di percaya bahwa tanaman pari berasal dari tubuh dewi Sri. Sehingga timbul suatu pandangan sakral terhadap lumbung. Kesakralan ini yang menyebabkan lumbung sebagai tempat penyimpanan pari diperlakukan sebagai tempat yang suci (Shomad 2016).

Namun seiring dengan berjalannya waktu dan perkembangan zaman, adat selamatan methik pari kini semakin memudar di masyarakat. Kondisi itu akan semakin mengurangi makna dan nilai dari keskralan tradisi masyarakat adat (Fransiska Idaroyani Neonnub \& Novi Triana Habsari, 2018). Oleh karena konteks

tersebut dipengaruhi globalisasi modern dalam kehidupan masyarakat yang semakin berkembang. Hal ini terlihat dari pelaksanaan adat selamatan pari yang dahulu dengan sekarang terdapat perbedaan. Salah satunya terkendala materi dan waktu. Sehingga adat selamatan methik pari hanya dilakukan oleh orangorang tua. Sehingga menyelenggarakan adat tersebut yang secara turun-temurun dilakukan, kini hanya dapat terlihat di pedesaan saja. Itu pun dilakukan oleh orang-orang tua bukan kalangan muda.

Maka perlu dilakukan penguatan tradisi nilai-nilai budaya lokal. Untuk mempertahankan eksistensi budaya lokal sebelum rantai pewarisnya terputus. Tradisi budaya lokal harus terus digali, diperkuat, dan dikembangkan dalam rangka menangkal arus globalisasi yang mempengaruhi eksistensi, legitimasi, dan keberlanjutan budaya lokal tersebut. Menghidupkan kembali budaya lokal tidak dengan sendirinya disebut Tradisi.

Proses Tradisi berfungsi untuk perbaikan aspek fisik, aspek ekonomi dan mampu mengenali dan memanfaatkan potensi lingkungan (sejarah, makna, keunikan lokasi dan citra tempat) (Sukatman, 2002). Indonesia yang memiliki banyak kultur atau kebudayaan yang beragam baik dari keberagaman suku, etnik, bahasa, pakaian tradisional, lagu-lagu daerah dan adat istiadat (Fara Dila, 2017). Mengenai kebudayaan pasti harus 
mengetahui istilah kebudayaan dari berbagai pakar bidang tersebut. Melville J. Herkovits berpendapat bahwa segala sesuatu yang terdapat di dalam masyarakat ditentukan oleh adanya kebudayaan yang di miliki masyarakat itu sendiri, yang dilanjutkan dari generasi ke generasi. Maka jika mengacu terhadap pendapat tersebut, kebudayaan dihasilkan dari pemikiranpemikiran atau konsepsi dari masyarakat itu sendiri, yang mereka percayai berasal dari nenek moyangnya yang kemudian secara turun temurun dipercaya oleh masyarakat sekitar (Melville, 2002).

Wujud dari kebudayaan juga merupakan bentuk tindakan yang direalisasikan melalui sistem upacara adat. Misalnya, wujud kelakuan dari sistem religi yang mempengaruhinya. Upacara adat yang merupakan pelaksanaan dan pengembangan konsep yang terkandung dalam keyakinan masyarakat, mampu memberikan inspirasi nilai positif, terutama sisi pesan moral bagi masyarakat.

Melalui pesan-pesan simbolik dalam upacara adat dapat menyadarkan manusia bahwa, dalam hidup dan kehidupan ini berlaku hukum kodrat yaitu kekuatan yang ada di luar kekuatan manusia yang bersifat mutlak (Melville, 2002). Budaya yang ada di Indonesia memang menarik untuk dikaji dan ditelisik maknanya. Indonesia masuk di era globalisasi yang erat kaitannya dengan paham yang sifatnya positivis atau realistik.
Namun jika kembali pada konteks bahwa rata-rata masyarakat di Indonesia lebih banyak yang religius atau masih percaya ke hal-hal non empiris, Indonesia notabene negara yang memiliki keanekaragaman kebudayaan unik dan penuh makna. Konteks tersebut yang mempengaruhi terbentuknya bermacam-macam kebudayaan yang diyakini masyarakat, selanjutnya secara lambat laun kebudayaan tersebut mengalir juga ke ranah bidang pertanian semisal bagi para petani pari (Yuliyani, 2010).

Sebelumnya, sudah diketahui bahwa banyak macam kebudayaan yang dilakukan oleh masyarakat petani khususnya petani pari. Memaknai nilai luhur sebuah kebudayaan tidak dapat dilepaskan dari implementasi dalam keseharian masyarakat, pilihan tindakan dalam menjalankan aktivitas seseorang dalam keseharian merupakan hasil dari nilai yang diinternalisasi dalam proses kebudayaannya (Nayati, 2008). Tulisan ini bertujuan untuk mengidentifikasi makna, proses pelaksanaan serta peran masyarakat dalam pelestariannya.

\section{Tinjauan Pustaka}

\section{A. Tradisi}

Dalam tradisi ada pula yang dimaksud dengan tradisi lisan. Suratman (2002), mengungkapkan bahwa tradisi lisan adalah semua kesenian, pertunjukan, atau permainan yang menggunakan tuturan 
lisan. Jika suatu kesenian tidak menggunakan atau tidak disertai ucapan lisan, maka tidak termasuk tradisi lisan. Sebaliknya, jika suatu cerita tidak ditradisikan (dipertunjukkan) dihadapan masyarakat pendukungnya, itu pun tidak termasuk tradisi lisan. Walaupun itu sastra lisan dan potensial jadi tradisi lisan. Masyarakat tidak pernah menjadi masyarakat bila kaitannya dengan masa lalunya tak ada (Suratman, 2002). Tradisi bukan sekedar produk masa lalu atau kebiasaan turun-temurun dari nenekmoyang yang masih dijalankan oleh masyarakat sekarang.

Akan tetapi sesuatu yang normatif dan kebenaran yang menjadi nilai yang telah teruji sebagai hal yang benar. Sekaligus sebagai kebaikan yang di yakini dalam komunitas. Tradisi merupakan sesuatu yang dinamis. Tradisi berguna untuk mengkaji manusia itu sendiri dan juga untuk mengembangkannya. Tradisi sebagai nilai merupakan sesuatu yang telah teruji kebenarannya. Dengan kata lain tradisi adalah sesuatu yang dianggap paling benar.

\section{B. Makna Semiotika Methik Pari}

Menurut Mansoer Pateda (2001) mengemukakan bahwa istilah makna merupakan kata-kata dan istilah yang membingungkan. Menurut Ullman (dalam Mansoer Pateda, 2001) mengemukakan bila makna adalah hubungan antara makna dengan pengertian. Menurut Ferdinand De Saussure (Chaer, 2007) mengungkapkan

bahwa pengertian makna sebagai pengertian atau konsep yang dimiliki atau terdapat pada suatu tanda linguistik. Bentuk makna diperhitungkan sebagai istilah sebab. Bentuk ini mempunyai konsep dalam bidang ilmu tertentu, yakni dalam bidang linguistik. Istilah makna walaupun membingungkan, sebenarnya lebih dekat dengan kata. Sering kita berkata, apa artinya pernyataan ini. Dengan menggunakan teori ini akan diketahui makna yang terkandung dalam tradisi methik pari.

Saussure dalam (Chaer, 2007) mengungkapkan pengertian makna sebagai pengertian atau konsep yang dimiliki atau terdapat pada tanda linguistik. Sedangkan Saussure (Chaer, 2007) mengungkapkan bahwa makna adalah pengertian atau konsep yang dimiliki atau terdapat pada tanda linguistik. Ditegaskan pula oleh Shipley (1962) berpendapat jika seseorang menafsirkan makna sebuah lambang, berarti ia memikirkan sebagaimana mestinya tentang lambang tersebut, yakni suatu keinginan untuk menghasilkan jawaban tertentu dengan kondisi-kondisi tertentu pula.

Dari pengertian para ahli bahasa tersebut, dapat dikatakan batasan tentang pengertian makna sangat sulit ditentukan karena setiap pemakai bahasa memiliki kemampuan dan cara pandang yang berbeda dalam memaknai sebuah ujaran atau kata. Saussure (dalam Chaer, 2007) 
berpendapat bahwa makna dapat dibicarakan dari dua pendekatan, yakni pendekatan analitik atau referensial dan pendekatan operasional. Pendekatan analitik ingin mencari makna dengan cara menguraikannya atas segmen-segmen utama. Sedangkan pendekatan operasional ingin mempelajari kata dalam penggunaannya. Pendekatan operasional menekankan bagaimana kata dioperasikan dalam tindak fonasi sehari-hari. Pendekatan operasional menggunakan tes substitusi untuk menentukan tepat tidak makna kata.

$$
\text { Misalnya, apakah kata }
$$
memberitakan sama dengan makna kata memberitahukan, apakah kata sebab sama maknanya dengan kata karena. Untuk itu dicoba dengan tes (khusus kata sebab dan karena). Selain dua pendekatan ini, pendekatan makna dapat dilihat pula dari hubungan fungsi yang berbeda di dalam bahasa. Pada umumnya orang membedakan pendekatan ekstensional dan pendekatan intensional. Dimaksud dengan pendekatan ekstensional ialah pendekatan yang memusatkan perhatian pada strukturstruktur konseptual yang berhubungan dengan unit-unit utama (bandingkan dengan pendekatan analitik).

\section{Metode Penelitian}

Penelitian ini dilakukan pada masyarakat Jawa di Desa Kalistail Kecamatan Genteng Kabupaten
Banyuwangi. Pertimbangannya adalah di Banyuwangi memiliki masyarakat Jawa yang masih menjalankan adat tersebut dan merupakan asli adat suku itu. Menurut Sutopo (2006) data kualitatif yang dikumpulkan terutama berupa kata-kata, kalimat atau gambar yang memiliki arti lebih bermakna dan mampu memacu pemahaman yang lebih nyata dari pada sekedar sajian angka atau frekuensi.

Pemanfaatan informan untuk membantu supaya dalam waktu yang relatif singkat banyak informasi yang dapat dijangkau dan memberikan informasi yang akurat. Sehingga menggunakan teknik Snowball dalam penentuan informan. Menurut Mursidi (2019) penelitian ini merupakan penelitian dasar. Informan adalah orang yang dimanfaatkan untuk memberikan informasi tentang situasi dan kondisi latar penelitian.

Dalam penelitian ini yang menjadi informan adalah pelaku adat untuk mengetahui proses dan makna adat methik pari dan masyarakat untuk mengetahui persepsi adat methik pari. Menurut H.B Sutopo (2006) sebelum merancang pelaksanaan penelitian, perlu dipahami bahwa terdapat dua jenis penelitian, yang dibedakan dari tujuan akhirnya. Dua penelitian tersebut meliputi penelitian dasar (basic research) dan penelitian terapan (applied research). Sehingga akan diperoleh data apakah masyarakat masih melakukan tradisi adat methik pari dan 
mengerti makna yang terkandung didalam upacara tersebut. Menurut Sutopo (2006), penelitian dasar merupakan jenis penelitian yang banyak dilakukan secara individual, terutama di lingkungan akademis. Jenis penelitian ini juga benarbenar dikuasai oleh peneliti sebelum mencoba untuk melakukan penelitian terapan. Pilihan bentuk rancangan dasarnya adalah tetap menggunakan rancangan penelitian dasar, yang dalam penelitian kualitatif berupa studi kasus (Sutopo, 2006).

\section{Hasil Dan Pembahasan}

\section{A. Sejarah Adat Methik Pari}

Dalam setiap penulisan sejarah yang bisa dilakukan adalah dengan mengunakan beberapa pendekatan, seperti mitos (mite), cerita rakyat, legenda, dan penelitian sejarah modern (Mursidi, 2019). Dalam analisis penelitian ini peran adat dan budaya sangat diperlukan untuk mengetahui apakah masyarakat masih melaksanakan adat ritual sesuai dengan pakemnya terdahulau atau hanya sekedar menjalankan saja. Pelakasanaaan adat methik pari yang dilakukan oleh mayarakat Kalistail tidak terlepas dari mitos dan legenda Dewi kesuburan.

Sejarah Adat Selamatan methik pari telah ada sejak zaman nenek moyang. Masyarakat Desa Kalistail mayoritas bermata pencaharian sebagai petani. Oleh karena profesi petani, maka di Desa
Kalistail menjalankan Adat selamatan methik pari. Sesajian yang biasa digunakan para petani yang merasa penting adalah sesajian dalam adat methik pari. Masyarakat Desa Kalistail ini mempercayai adanya Dewi sri (Dewi pari) atau mbok sri (bagi sebutan orang Jawa) sebagai penunggu lahan pertaniannya.

Adat selamatan methik pari ini bertujuan untuk menghormati Dewi sri supaya menjaga lahan pertaniannya dari gangguan hama tanaman pari, sehingga mendapatkan hasil panen yang berlimpah. Pelaksanaan adat selamatan methik pari di Desa Kalistail, yaitu menyiapkan sesajian sebelum melaksanakan prosesi adat selamatan methik pari. Maka perlu disiapkan beberapa bahan, yaitu Uborampe yang berupa sesajen, kaca, sisir, gampung atau ani-ani untuk memotong pari, pisang raja setangkep, kemenyan, dan seikat jerami yang dibungkus.

Selain itu, disiapkan pula nasi putih yang dibentuk tumpeng, ayam beteteng (ayam tanggung, yang muda dan sehat), jajan pasar, urap-urap, sambal goreng, tempe dan tahu. Jenang merah, jenang putih, cokbakal yang berisi jenis rempahrempah, garam, beras sedikit, ikan asin, rokok, telur dan bunga-bunga. Dalam hal memasak makanan untuk adat selamatan methik pari atau selamatan apapun, tidak mengenal kata incip atau tidak boleh di cicipi. Sebab jika di incip berarti makanan yang disuguhkan merupakan makanan sisa 
atau bekas. Jadi dalam menyajikan sebagai acara wujud syukur terutama kepada Tuhan Yang Maha Kuasa. Sehingga bahanbahan yang disiapkan harus bagus dan pilihan serta tidak boleh di incip. Untuk pengantin Dewi sri bahan uborampe, diantaranya daun tebu, daun pulutan, daun kelapa muda yang muda (janur), daun lengkuas dan daun dadap srep. Pelaksanaan prosesi di mulai dari tetua adat dan rombongan bersama-sama pergi ke sawah.

Setelah siap semua uborampe, tumpeng nasi putih, ayam beteteng dan gagar mayang dibawa ke sawah untuk mulai dilaksanakan prosesi selamatan methik pari. Pertama tetua adat memotong bagian ayam, meliputi, kepala, ceker (kaki ayam), sayap, brutu (anus), dan jerohan (hati, rempela, jantung dan usus). Semuanya ditaruh di wadah takir yang diletakkan di dekat uborampe dan gagar mayang. Selanjutnya tetua adat mengambil jerami yang sudah diberi menyan yang kemudian dibakar, sambil tetua adat membaca do`a.

Lebih lanjut, tetua adat mengambil air untuk disiramkan ke pinggiran gunting yang digunakan untuk memotong tangkai pari. Makna dari adat selamatan methik pari adalah sebagai penghubung manusia antara leluhur dan Tuhannya supaya diberi kemudahan, kelancaran serta keselamatan tatkala menggarap lahan pertanian. Selain itu, dapat mempererat persaudaraan serta saling membantu dalam terciptanya kepedulian masyarakat. Berbagai upaya dilakukan untuk memberi unsur ketahanan kearifan budaya selamatan methik pari Desa Kalistail terhadap pengaruh globalisasi. Di dalam tradisi atau adat lokal sudah sepatutnya terdapat usaha untuk mengatasi pengaruh negatif dari globalisasi tersebut terutama dalam hal meminimalisir pergeseran nilai-nilainya.

Supaya kearifan budaya adat selamatan methik pari yang ada di masyarakat Desa Kalistail tetap lestari, dilakukan penanaman nilai-nilai budaya. Wujudnya adalah dengan melakukan dan tetap konsisten melaksanakan adat tersebut. Selain itu mengajak generasi muda sebagai pewaris selanjutnya untuk belajar dan mengerti terhadan nilai adat selamatan methik pari tersebut.

\section{B. Selamatan Methik Pari}

Sejarah adat selamatan methik pari ini merupakan warisan dari nenek moyang dahulu yang bermula dari seorang Dewi Sri menikah dengan Joko Sedono. Kemudian Dewi Sri di suruh bertapa di gunung Tidar sampai bertahun-tahun lamanya, munculah Pari yang merupakan jelmaan dari Dewi Sri di gunung tidar yang melambangkan untuk makanannya orang sedunia. Sebenarnya Joko Sedonono tidak mau pisah dengan Dewi Sri, dia ingin menjadi apa pun supaya bisa bersama terus dengan Dewi Sri. Joko Sedono mengatakan bahwa "aku mau dijadikan apapun yang penting bisa bersama mbok Dewi Sri, dijadikan 
ganjelnya lumbung pun tidak apa-apa". Dari kejadian itu Joko Sedono menjadi jenis-jenis tanaman palawija dengan segala makanan, selain nasi yang termasuk kolo pendem. Misalnya, uwi, sabrang, dan sawi. Sehingga masyarakat mempercayai bahwa pari tersebut merupakan Dewi sri yang menunggu pari. Untuk menghormati dan mensyukuri atas rezeki serta keselamatan dalam mengolah lahan pertanian, maka masyarakat mengadakan adat selamatan methik pari.

Selamatan methik pari di Desa Kalistail ini memang ada dan masih dilakukan oleh para petani menjelang masa panen tiba. Namun terkadang memang satu Desa dengan Desa lain berbeda dalam proses pelaksanaan. Hal ini dikarenakan sesuai masing-masing permintaan sawah, masyarakat petani Desa Kalistail meyakini bahwa tanaman Pari tersebut ada penunggunya, yaitu seorang Dewi sri (dewi kesuburan).

Menurut cerita, Dewi sri menikah (Dewi kesuburan) dengan Joko Sedono (sandang pangan). Dewi sri tersebut merupakan Dewi pari yang menjaga lahan pertanian. Oleh karena, sebagai ungkapan terimakasih terhadap Dewi sri, para petani melakukan prosesi adat ini. Adat selamatan methik pari sudah ada dari nenek moyang atau leluhur terdahulu. Tujuan diadakan adat selamatan methik pari ini adalah supaya tanaman pari menjadi bagus dan hasil panen melimpah, serta tidak ada gangguan penyakit yang menyerang tanaman pari. Dalam pelaksanannya sama yaitu menjelang panen tiba, pari sudah tua menguning, do`a yang diucapkan berupa do`a dalam bahasa Jawa dan do`a sesuai ajaran Islam, yang intinya meminta keselamatan. Pelaksanakan selamatan methik pari tidak sembarangan dalam memilih hari. Hari yang baik dalam melaksanakan adat selamatan methik pari yaitu hari Jawa dan harus genap.

Misalnya, kamis kliwon, rinciannya adalah hari kamis berangka 8 dan kliwon berangka 8 , jika dijumlah 16 . Sehingga dalam memotong pari untuk temanten Sri itu sejumlah 18 tangkai pari. Do`a yang diucapkan adalah do`a selamat, yaitu do`a dalam bahasa Jawa dan do`a Islam yang ditujukan kepada yang maha kuasa supaya panen berlimpah. Selain itu, juga diperuntukkan yang mempunyai sawah dalam pengerjaan menanam pari hingga panen. Pelaksanaan adat selamatan methik pari dilakukan di rumah Bapak Sukardi, selaku narasumber (responden).

Dari informan tersebut diperoleh keterangan bahwa yang dipersiapkan Pertama, adalah sesajen berupa sisir, kaca, gunting (untuk memotong Pari), benang, blangkokan (sabut kelapa), dan kemenyan. Kedua, cokbakal berbentuk takir dari daun pisang yang berisikan bunga warna-warni, rokok, telur, rempah-rempah. Ketiga, kembar mayang yang berupa daun pulutan, janur, daun kluwih, daun tebu diikat jadi 
satu. Keempat, nasi dan lauk ayam kampung yang dipanggang utuh dan sambal parutan kelapa, yang kemudian ikut dalam adat selamatan methik pari.

\section{Makna Adat Tradisi Methik Pari}

Makna dari adat ini adalah sebagai penghubung manusia antara leluhur dan Tuhan, sehingga diberi keselamatan dalam penggarapan lahan pertanian. Dalam persiapan terdapat gagar mayang yang mempunyai makna sebagai berikut: daun polutan artinya saroh, janur artinya nur (cahaya), daun dadap srep artinya adem, ayem, asrep. Daun lengkuas artinya bahan bumbu uborampe (perlengkapan) meliputi Cokbakal berisi telur, bumbu dapur atau jenis rempah-rempah (merica, ketumbar, jahe, kencur, kunyit, kacang hijau, beras) dan rokok. Sesajennya yaitu ayam panggang, sambel kelapa.

Dari prosesi uborampe tersebut mengandung makna dalam prosesi selamatan methik pari, diantaranya terbentuknya sistem kekeluargaan antara masyarakat, kerukunan antar umat beragama, serta selalu bersyukur kepada Tuhan Yang Maha Kuasa yang telah memberikan kesuburan terhadap tanaman pari. Menurut informan Bapak Tukiran mengemukakan makna berlangsungnya prosesi adat selamatan methik pari adalah untuk saling menghormati apa yang leluhur dahulu lakukan. Supaya kegiatan apa pun yang di lakukan berjalan lancar, maka harus memberikan penghormatan kepada penjaga alam. Di dalam prosesi adat tersebut mempunyai makna untuk memberikan penghormatan kepada Dewi Sri. Oleh karena telah memberikan hasil panen yang bagus dan berlimpah, namun dengan cara berdo`a kepada Tuhan melalui perantara Dewi Sri yang menjaga pari tersebut. Menurut Bapak Sukardi, makna dari adat selamatan methik pari ini adalah sebagai penghubung manusia antara leluhur dan Tuhannya dan akan diberi keselamatan dalam penggarapan lahan pertaniannya.

Berdasarkan pernyataan tersebut dapat mengambil analisis apabila makna prosesi adat tersebut juga sebagai penghubung manusia antara leluhur dan Tuhan. Sehingga akan diberikan keselamatan dalam penggarapan lahan pertanian. Dalam persiapan terdapat gagar mayang yang memiliki makna sebagai berikut: daun polutan artinya saroh, janur artinya nur (cahaya), daun dadap srep artinya adem, ayem, asrep. Daun lengkuas artinya bahan bumbu.

Untuk methik pari yang ingin dipetik menggunakan ani-ani atau gampung. Jika zaman sekarang menggunakan gunting. Menurut informan mbah Supinah, memetik pari harus menggunakan gampung atau ani-ani. Kalau tidak memakai gampung dan ani-ani maka tidak boleh (tidak elok). Uborampe (perlengkapan), meliputi cokbakal berisi telur, bumbu dapur sejenis rempah-rempah 
(merica, ketumbar, jahe, kencur, kunyit, kacang hijau, beras) serta rokok. Sesajennya berupa ayam panggang dan sambal kelapa. Kelengkapan sesajen tersebut sesuai dengan adat sawah daerah setempat.

\section{Pelaksanaan Tradisi Methik Pari}

Dalam pelaksanaan methik pari dilakukan di sawah. Oleh karena yang di selamati merupakan sawah, maka harus dilaksanakan disawah yang akan dipetik parinya. Semua makanan dan sesajian dibawa ke sawah untuk di do`akan. Kalau tidak dilaksanakan methik Pari berakibat celaka dan nagihi (minta hak) dari penjaga sawahnya yang merupakan makhluk tidak nyata. Dahulu ada kejadian bahwa yang biasanya sawah dipetik terus tidak dipetik, secara tidak langsung diantara keluarga mereka terkena musibah. Misalnya, sakit bahkan sampai meninggal.

Perumpamaan saja jika seorang kakak disuruh menjaga adiknya, dan ibunya tidak mengerti atau tidak memberi imbalan, pasti kakak ini akan menagih ke ibunya untuk meminta upah. Apabila tidak diberi upah akan marah. Berikut do`a yang biasa diucapkan dalam pelaksanaan selamatan methik pari.

\section{Doa selamat untuk metik PARI}

Bismillahhirohmannirohim, Wiji Pari soko suwargo, tumurun ing arjo podo.

Isun tandur bumi bopo kuoso.

Oyot kawat wite wesi kembang mas isi seloko.

Rehne wes titi mongso tak boyong muleh.
Tak enggo ngingoni anak bojoku sak keluargaku ojo kaget.

Sun gigas tanggan hiro seng tak ngge nyigar wesi polusan.

Adem asrep-asrep, saking kersane allah.

Lhailahaillawloh

muhammadurosululwoh

\section{Artinya:}

(Bismilahirohmannirohim,

Biji Pari dari surga, turun bersamasama.

Saya tanam dibumi pertiwi dan bapak penguasa.

Akar kawat pohon besi bunga mas berisi Karena sudah waktunya untuk saya bawa pulang.

Saya gunakan untuk menghidupi anak istri sekeluarga jangan kaget.

Saya ambil tangan mu yang kugunakan untuk memotong dengan besi polutan.

Tenang tentram dari ridhonya Allah)

Sekarang sudah jarang orang melakukan adat selamatan methik pari. Alat yang digunakan sekarang untuk methik bukan ani-ani (gampung), melainkan gunting, silet, dan arit. Pelaksanaan adat selamatan methik pari zaman sekarang dilakukan di rumah. Danyang itu orang yang punya sawah, sehingga meminta keselamatan bagi danyang yang mempunyai sawah dalam mengolah sawahnya.

Aturan dalam penyajian adat selamatan methik itu terserah yang mempunyai hajat, sehingga tidak memaksakan harus lengkap. Zaman dahulu masih banyak tempat yang keramat (angker) yang identik ada penunggu berupa roh-roh halus. Berbeda dengan zaman sekarang yang sudah tidak ada tempat keramat, sebagian orang sekarang 
sudah tidak mempercayai adanya makhluk halus yang masih ada disekitarnya. Mereka hanya berfikir yang rasional dan masuk akal. Oleh karena, adat yang masih kental dengan ritus dan mistis sudah jarang dilakukan. Sebagai generasi dari nenek moyang tanaman pari dan mendapatkan hasil panen yang berlimpah, maka pelaksanaan adat selamatan methik pari ini masih dilakukan masyarakat Desa Kalistail Kecamatan Genteng.

Perubahan sesajian yang digunakan dalam pelaksanaan adat selamatan methik pari adalah perubahan dalam pelaksanaan adat dan sesajian. Pada zaman dahulu Uborampe yang disiapkan berupa sesajen, kaca, sisir, gampung dan ani-ani untuk memotong pari, pisang raja setangkep, kemenyan, dan seikat Jerami yang dibungkus. Selain itu, di siapkan nasi putih dibentuk tumpeng, ayam beteteng (ayam tanggung, yang muda dan sehat), jajan pasar, urap-urap, sambal goreng, tempe, dan tahu.

Jenang merah, jenang putih, cokbakal yang berisi jenis rempah-rempah, garam, beras sedikit, ikan asin, rokok, telur, serta bunga-bunga. Jenang merah melambangkan setetes darah merah dari ibu, jenang putih melambangkan setetes darah putih dari bapak, jajan pasar artinya pemberi kebahagiaan untuk semua yang ikut dalam selamatan, cok bakal artinya bakal atau sesuatu yang masih permulaan, rokok merupakan kesenangan, dan kemenyan untuk bau harum-haruman. Sedangkan zaman sekarang yang disiapkan Uborampe (perlengkapan) antara lain Cokbakal berisi telur, bumbu dapur dan jenis rempah-rempah (merica, ketumbar, jahe, kencur, kunyit, kacang hijau, beras) serta rokok. Sesajennya yaitu ayam panggang, sambel kelapa. Gagar mayang yang memiliki makna diantaranya daun polutan artinya saroh, janur artinya nur (cahaya), daun dadap srep artinya adem, ayem, asrep .

Daun lengkuas artinya bahan bumbu Uborampe, gunting untuk memotong, kaca untuk berkaca saat berdandan oleh mbok Sri, dan sisir untuk menyisir rambut mbok Sri. Mengenai adat selamatan methik pari seharusnya dalam penyajian sesajian tetap lengkap seperti dulu. Namun karena perkembangan zaman sedikit demi sedikit diperkecil, sehingga penyajiannya semakin sedikit. Dahulu memakai gampung untuk memotong Pari sekarang memakai gunting.

Seharusnya tetap menggunakan gampung, selain sebagai pelestarian alat tradisional kegunaannya tidak kalah dengan gunting dan arit. Jajan pasar pun sudah tidak dipakai lagi sehingga pemaknaan dari penyajian telah berubah. Dalam pelaksanaan adat selamatan methik pari di Desa Kalistail, ada masyarakat dalam melaksanakan adat selamatan methik pari tersebut tidak membawa nasi tumpeng putih dan ayam beteteng. Akan 
tetapi hanya membawa cokbakal, jerami dan kemenyan sebagai ritual selamatan methik pari, serta hanya seorang diri tanpa membawa teman atau saudara. Sedangkan sesajian nasi dan lauk di taruh di rumah. Kemudian membaginya di rumah tanpa mengundang tetangga untuk makan bersama, tetapi langsung diantar ke tetangga. Dari kedua pendapat tersebut sangat berbeda dalam pelaksanaan adat selamatan methik pari di Desa Kalistail.

Seharusnya pelaksanaan adat di lakukan di sawah. Hal ini karena yang di selamati itu adalah sawah. Dari hal ini juga terdapat sesajian yang semakin dikurangi sehingga tidak lengkap. Masyarakat Desa Kalistail hanya menyediakan sesajian yang pokok utama saja. Menurut hasil penelitian sesajian yang sesuai perkembangan zaman sekarang juga tidak apa-apa. Sebab adat selamatan methik pari tersebut merupakan perwujudan syukur karena telah mendapatkan rezeki dari hasil panen Pari (padi), sehingga mereka bersedekah.

\section{E. Upaya Masyarakat Dalam Pelestarian}

\section{Adat Selamatan Methik Pari Era Globalisasi}

Berdasarkan analisa hasil penelitian dinyatakan bahwa pengaruh globalisasi sangat terlihat jelas di dalam pelaksanaan adat selamatan pari. Pada zaman dahulu untuk memberikan sesajian harus lengkap. Namun dalam perkembangan dan pengaruh globalisasi mulai terjadi pergeseran dalam pemaknaan. Terutama segi pengadaan sesajian yang mengalami perubahan. Misalnya, tatkala zaman dulu untuk memotong pari memakai ani-ani, tetapi sekarang menggunakan gunting. Dalam menyajikan perlengkapan adat sekarang sudah disesuaikan dengan yang berhajat dan, tidak ada unsur pemaksaan ketersediaan menu sajian seperti dulu kala. Pengaruh globalisasi dalam tradisi atau adat lokal, maka sudah sepatutnya ada upaya untuk mengatasi pengaruh negatif dari globalisasi tersebut.

Supaya budaya adat selamatan pari yang ada di masyarakat, yang mana dilakukan penanaman nilai-nilai budaya diantara masyarakat. Sehingga perlu dilakukan internalisasi tradisi budaya setempat guna memperkuat budaya daerah. Sehingga generasi sekarang ini, khususnya Desa Kalistail dapat melestarikan budaya adat selamatan methik pari dan bisa dijadikan salah satu potensi kebudayaan daerah yang ternilai.

\section{Penutup}

\section{Kesimpulan}

Pelaksanaan adat selamatan methik pari yang dilakukan oleh masyarakat Kalistail masih terjaga dengan baik. Walaupun prosesi pelaksanaan adat sudah mulai jarang dilakukan. Salah satu penyebab dari berkurangnya pelaku adat dikarenakan penjaga tradisi tidak bisa memberikan pemahaman kepada generasi sekarang tentang makna nilai-nilainya. 
Semangat yang dilakukan oleh masyarakat Kalistail hanya sekedar melaksanakan tradisi yang belum paham, tentang makna yang terkandung dalam prosesi adat tersebut. Peran penjaga tradisi terutama pemangku adat harus bisa memberikan pemahaman kepada generasi muda. Sehingga adat dan tradisi bisa dilakukan sesuai dengan pakem dan maknanya.

\section{Daftar Pustaka}

Anggoro, M. T, dkk. (2007). Metode Penelitian. Jakarta: Universitas Terbuka.

Ria, F. D. (2017). Ritual Keleman Dan Metik Bagi Petani Desa Wonokasian, Kecamatan Wonoayu, Sidoarjo. Jurnal Paradigma, 05 (03).

Chaer, A. (2007). Linguistik Umum. Jakarta: Rineka Cipta

Gouillart, F. \& Kelly, J. (1995). Transforming the Organization. Maidenhead, McGraw-Hill.

Hardt, M., \& Negri, A. (2004). The Long March of Democracy. dalam Multitude: War and Democracy in the Age of Empire, New York: the Penguin Press.

Hoed, B. H. (2014). Semiotika Dan Dinamika Sosial Budaya. Depok: Komunitas Bambu.

Mursidi, A., \& Soetopo, D. (2019). Kecamatan Blimbingsari Dan Kecamatan Bangorejo Dalam Sudut Pandang Ilmu Toponomi Di Wilayah Kabupaten Banyuwangi. Jurnal. Khasah Pendidikan, 12 (1).

Melville J. H,. \& Malinowski, B. (2002). The Symbolic Construction of Community. Routledge: New York.

Lucian W. P. (1966). Globalisasi dan nasionalisme Indonesia. Surabaya Post, 20 April.
Mansoer, P. (2001). Semantik Leksikal. Jakarta: Rineka Cipta.

Neonnub, F. I. \& Habsari, N. T. (2018). Belis: Tradisi Perkawinan Masyarakat Insana Kabupaten Timor Tengah Utara (Kajian Historis dan Budaya Tahun 2000-2017). Agastya: Jurnal Sejarah dan Pembelajarannya, 8(01), 107-126. http://doi.org/10.25273/ajsp.v8i0 1.2035

Shipley. (1962). Dictionary of World Literature. New York. Littlefield

Shomad, A. (2016). Studi Semiotika Perang Bangkat: Era Tradisional Dan Era Modernisasi. Jurnal Historia, 4(2).

Sukatman. (2002). Butir- Butir Tradisi Lisan. Yogyakarta: Tim Laks Bang.

Sutopo. H.B. (2006). Metode Penelitian Kualitatif Dasar Teori dan Penerapanya Dalam Penelitian. Surakarta: UNS Press.

Rizqi, D. (2012). Pengertian Budaya, Kebudayaan adat.

RPJMD Desa Kebaman Kecamatan Srono Tahun 2014-2019.

Wawancara Sukardi (10 mei 2015, 19.0020.30 WIB).

Wawancara Supinah (12 Mei 2015, 10.0012.00 WIB)

Wawancara Agus Budianta (10 Mei 2015, 11.00 WIB)

Wawancara Tukiren (15 Mei 2015, 09.00$11.00 \mathrm{WIB})$ 